\title{
Preliminary results on salicylic acid treatment on brown rot caused by Monilinia laxa on Jumbo Cot fruit, Prunus armeniaca $\mathbf{L}$.
}

\author{
Ezzat, A. ${ }^{1,2}$, Szabó, Z. ${ }^{1}$, Nyéki J. ${ }^{1}$ \& Holb, I.J. ${ }^{1}$ \\ ${ }^{I}$ Institute of Horticulture, University of Debrecen, H-4015 P. O Box. 36. Debrecen, Hungary \\ ${ }^{2}$ Horticulture Department. Faculty of Agriculture. University of Kafelelsehikh, Egypt
}

Summary: The effect of salicylic acid on reducing brown rot caused by Monilinia laxa infection in postharvest apricot fruit Prunus armeniaca L. Freshly harvest Jumpo Cot fruit were treated with water as control treatment and other group treated with salicylic acid $2 \mathrm{Mm}$ as induced resistance treatment, Fruits were infected by M. laxa $\left(1 \times 10^{-3}\right.$ spores $\left.\mathrm{ml}^{-1}\right)$ and incubated at $25{ }^{\circ} \mathrm{C}$ for 2,4 and 6 days. Treatment fruits with salicylic acid resulted in direct effect on mycelial growth as in the salicylic acid treatment the growth reached to $45 \%$ after 6 days of incubation while in the control treatment it reached to $100 \%$.

Key words: apricot fruit, salicylic acid, brown rot, Monilinia laxa, disease resistance

\section{Introduction}

Brown rot, caused by Monilinia laxa (Aderhold \&Ruhland) is a devastating disease of apricot (Prunus armeniaca L.). The disease is endemic in Europe and causes epidemics in most stone fruit orchards (Wormald, 1954; Byrde \& Willets, 1977; Batra, 1991; Holb, 2004). Brown rot has been resulting in blossom blight in rainy springs and in fruit rot in rainy summers in Hungarian apricot orchards. Postharvest fungal pathogens result in major losses of fruits and vegetables and can be controlled effectively by synthetic chemical fungicides

Many reports have shown that induced disease resistance in plants by biotic and abiotic elicitors is a very effective method for restricting the spread of fungal infection (Droby et al., 2002; Qin et al., 2003). Resistance of plants to pathogens is based on both constitutive defense mechanisms such as pre-existing antimicrobial compounds and inducible defense mechanisms. Induced disease resistance in plants by biotic or abiotic treatments is a very attractive strategy for controlling diseases

This experiment aimed to study the effect of salicylic acid on the in vitro growth of M. laxa.

\section{Materials and methods}

\section{Isolation of fungi}

$M$. laxa were isolated from decayed plum fruit. The fungi were maintained on PDA at $4{ }^{\circ} \mathrm{C}$. Spores of M. laxa were obtained from 2-week-old cultures incubated at $25{ }^{\circ} \mathrm{C}$ by flooding the cultures with sterile distilled water containing $0.05 \%$ (v/v) Tween 80 . The suspensions of spores were filtered through four layers of sterilized cheese cloth. The concentrations of spores were adjusted to $\left(1 \times 10^{-3}\right.$ spores $\left.\mathrm{ml}^{-1}\right)$ with the aid of a haemocytometer

\section{Mycelial growth}

The effects of Salicylic acid on mycelial growth were assayed by the method of Yao \& Tian (2005a). Salicylic acid solution mixed with molten PDA-agar to give a total volume of $20 \mathrm{~mL}$ per petri plate (diameter: $90 \mathrm{~mm}$ ). S.A concentration was $2 \mathrm{Mm}$ in the PDA-agar. After the agar had solidified, $5 \mathrm{~mm}$ disks of $M$. laxa were placed in the center of each petri plate. Plates were incubated at $20^{\circ} \mathrm{C}$.Colony diameter was determined 24, 48 and 72h after inoculation. Each treatment was replicated three times and the experiment was repeated twice. Mycelial growth of M. laxa on PDA was expressed as growth rate, which was calculated according to the following formula. Growth rate $(\%)=($ colony diameter after inoculation $-5 \mathrm{~mm}) / 5 \mathrm{~mm} \times 100$.

\section{Data analysis}

Experiments were performed using a completely randomized design. All statically analyzes were performed with SPSS program. The data were analyzed by one-way analysis of variance (ANOVA). Means separation was performed by Duncan's multiple range tests. Differences at $\mathrm{p}<0.05$ were considered as significant. 


\section{Results and discussion}

\section{Effect of salicylic acid treatment on mycelial growth of Monilinia laxa in vitro}

Salicylic acid treatment markedly reduced the growth rate of M. laxa in vitro figure (1). Growth rate of M. laxa in PDA media without salicylic acid rose to around $50 \%$ during 2 days after incubation at $25{ }^{\circ} \mathrm{C}$ while the rate rose to about $20 \%$ in PDA media inoculate with $2 \mathrm{Mm}$ salicylic acid with significantly differences $(p<0.05)$. The growth rate of $M$. laxa in control treatment increased dramatically after 4 days and 6 days to around $90 \%$ and 140\%, respectively. In case of salicylic acid treatment, the rate of mycelial growth ranged between

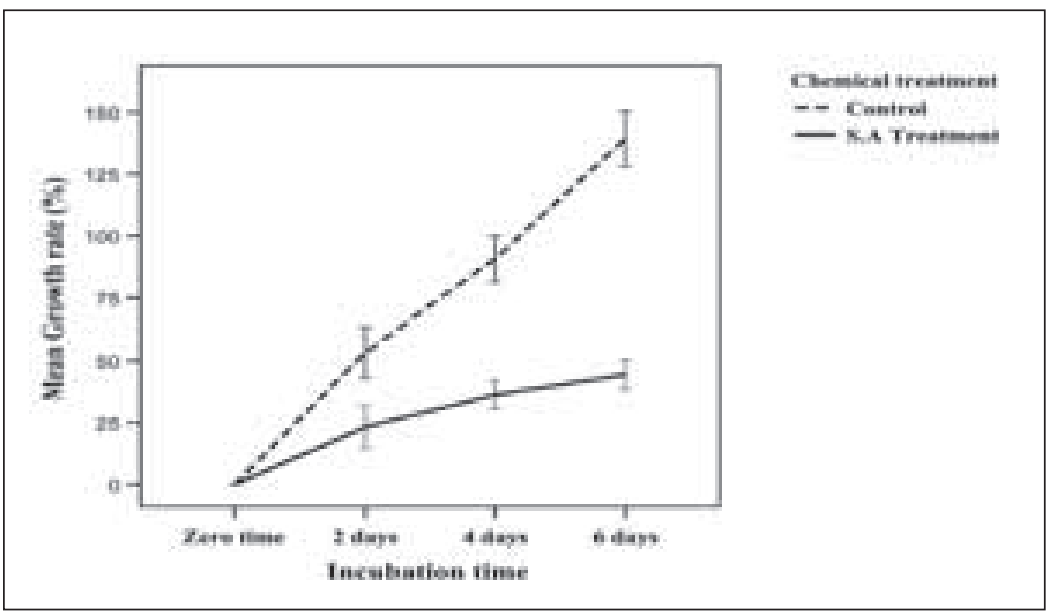

Figure 1. Effect of salicylic acid on mycelial growth of Monilinia laxa in vitro.

Data are expressed as the mean of triplicate assays. Vertical bars represent the standard errors of means approximately $25 \%$ to $45 \%$ after 4 days and 6 days, respectively with significant difference in comparison to control treatment $(p<0.05)$.

Inducing resistance is another important strategy for reducing the diseases in plant as well as in harvested fruit and vegetables, which is attractive because the induced disease resistance utilizes the plant's own defense mechanisms and is either far less toxic than fungicides or nontoxic (Wilson et al., 1994; Kuć, 2001; Terry and Joyce, 2004; Walters et al., 2005; Elmer and Reglinski, 2006). For example, salicylic acid (SA), a best known elicitor, can induce local and systemic resistance in many plant tissues (Rojo et al., 2003; GarciaBrugger et al., 2006) including pear fruit (Cao et al., 2006; Tian et al., 2006).

In this study, found that salicylic acid treatment could significantly reduce $M$. laxa growth in vivo as Cao et al. (2008) reported in case of MeJA in loquat fruit. It is postulated that the control of the disease is directly because of the inhibitory effect of MeJA on pathogen growth, and indirectly because of the induced disease resistance triggered by enhanced $\mathrm{H}_{2} \mathrm{O}_{2}$ levels. Also these results were in the same way with Yao et al. (2005b), they reported that salicylic acid with a concentration of $2 \mathrm{mM}$ showed direct fungitoxicity on $M$. fructicola and significantly inhibited mycelial growth and spore germination of the pathogen in vitro. The results reported that the Salicylic acid has direct effect on reducing the lesion diameter and disease incidence with significantly differences $(p<0.05)$ and this finding is too clear in case of unwounding treatment these results are in the same trend like the finding of Yao et al. (2005ab) they reported that preharvest treatments with $2 \mathrm{mM}$ salicylic acid (SA) and $0.2 \mathrm{mM}$ methyl jasmonate (MeJA) significantly reduced lesion diameters on sweet cherry fruit caused by M. fructicola compared with control post-harvest treatments.

\section{Acknowledgements}

This research was supported partly by a grant of the Hungarian Scientific Research Fund (K78399 and OTKA K108333) and by the European Union and the State of Hungary, co-financed by the European Social Fund in the frameworkof TÁMOP-4.2.4.A/ 2-11/1-2012-0001 'National Excellence Program' under the project number: A2-SZJTOK-13-0061.

\section{References}

Batra, L. R. (1991): World species of Monilinia (Fungi): Their ecology, biosystematics and control. Mycologia Memoir No. 16, J. Cramer, Berlin, 246 pp.

Byrde, R. J. W. \& Willetts, H. J. (1977): The brown rot fungi of fruit. Their biology and control. Pergamon Press, Oxford, 171 pp.

Cao, S. F.; Zheng, Y. H.; Yang, Z. F.; Tang, S. S.; Jin, P.; Wang, K. T.; Wang, X. M. (2008) Effect of methyl jasmonate on the inhibition of Colletotrichum acutatum infection in loquat fruit and the possible mechanisms. Postharvest Biol. Technol., 49: 301-307.

Droby,S.,Vinokur,V.,Weiss,B.,Cohen,L.,Daus,A.,Goldschmi dt,E.E.,Porat,R. (2002). Induction of resistance to Penicillium digitatum in grapefruit by the yeast biocontrol agent Candida oleophila. Photopathology 92: 393-399.

Elmer, P.A.G., Reglinski, T., (2006): Biosuppression of Botrytis cinerea in grapes. Plant Pathology 55: 155-177.

Garcia-Brugger, A., Lamotte, O., Vandelle, E., Bourque, S., Lecourieux, D., Poinssot, B., Wendehenne, D., Pugin, A., (2006). Early signaling events induced by elicitors of plant defenses. Molecular Plant-Microbe Interactions 19: 711-724. 
Holb I J. (2004): The brown rot fungi of fruit crops (Monilinia spp.). II. Important features of their epidemiology. International Journal of Horticultural Science 10 (1): 17-35.

Kuć, J., (2001): Concepts and direction of induced systemic resistance in plants and its application. European Journal of Plant Pathology 107: 7-12.

Qin, G.Z., Tian, S.P., Xu, Y., Wan, Y.K., (2003): Enhancement of biocontrol efficacy of antagonistic yeasts by salicylic acid in sweet cherry fruit. Physiol. Mol. Plant Pathol. 62: 147-154.

Rojo, E., Solano, R., Sánchez-Serrano, J.J., (2003): Interactions between signaling compounds involved in plant defense. Journal of Plant Growth Regulation 22: 82-98.

Terry, L.A., Joyce, D.C., (2004): Elicitors of induced disease resistance in postharvest horticultural crops: a brief review. Postharvest Biology and Technology 32: 1-13.

Tian, S., Wan, Y., Qin, G., Xu, Y., (2006): Induction of defense responses against Alternaria rot by different elicitors in harvested pear fruit. Applied Microbiology and Biotechnology 70: 729-734.
Walters, D.,Walsh, D., Newton, A., Lyon, G., (2005): Induced resistance for plant disease control: Maximizing the efficacy of resistance elicitors. Phytopathology 95: 1368-1373.

Wilson, C.L., Ei-ghaouth, A., Chalutz, E., Droby, S., Stevens, C., Liu, J.Y., Khan, V., Arul, J., (1994): Potential of induced resistance to control postharvest diseases of fruits and vegetables. Plant Disease 78: 837-844.

Wormald, H. (1954): The brown rot disease of fruit trees. Ministry of Agriculture, Fisheries and Food, Technical Bulletin no. 3, London

Yao, H. J.; Tian, S. P. (2005a): Effects of pre- and post-harvest application of salicylic acid or methyl jasmonate on inducing disease resistance of sweet cherry fruit in storage. Postharvest Biol. Technol., 35: 253-262.

Yao, H.J., Tian, S.P., (2005b): Effects of a biocontrol agent and methyl jasmonate on postharvest disease of peach fruit and the possible mechanism involved. J. Appl. Microbiol. 98: 941-950. 